\section{The effects of chronic doses of tricyanoaminopropene on water consumption in the rat*}

\author{
PAUL R. SOLOMON and DAVID L. MORSE† \\ State University College, New Paltz, N.Y. 12561
}

Twenty albino rats of the Wistar strain were assigned to one of four groups ( 7 , 14 , or $28 \mathrm{mg} / \mathrm{kg}$ TRIAP) or a control group receiving $3 \%$ tragacanth. All Ss were given chronic injections of the appropriate drug for a 35-day period. The amount of water consumed was measured over a 3-day period, and it was found that no differences existed between the groups. A dose-related tolerance mechanism was discussed.

The drug tricyanoaminopropene (TRIAP) has been related to increased neuronal RNA in the Dieters' nerve cells of the rabbit (Egyházi \& Hydén, 1961). It has been suggested that this change in nucleoprotein and nucleic-acid metabolism may be related to learning and memory.

Behavioral examination of the effects of acute administration of the drug have given contradictory results. Gurowitz, Gross, \& George (1968) found TRIAP to be detrimental in a water-motivated passive avoidance task. They have suggested that the main effects of a single dose of TRIAP seem to be that of a mild stimulant. Morse \& Solomon (1970), in employing a food-reinforced DRL situation to control for possible stimulant effects, found the drug to facilitate learning.

One possible explanation for these discrepancies may be the failure to account for certain motivational variables. For example, Gurowitz (1969) has found that acute administration of TRIAP caused a significant increase in water consumption. Due to this finding, he has cautioned that studies involving TRIAP must take into account the different motivational levels of the animal.

Since most of the recent work with TRIAP involves chronic administration, it is necessary to begin to examine the relationship of multiple doses of the drug to the motivational level of the animal. It will be the purpose of this study to examine the effects of chronic administration of TRIAP on water consumption in the rat. It is expected that as dosage increases, the water

*This research was supported in part by Grant 26-7119A from the State of New York Research Foundation.

tThe authors wish to thank paul w, O'Connell of the Upjohn Company for generously providing the compound $(\mathrm{U}-9189)$ used in this study. consumption will also increase. SUBJECTS

The Ss used in this study consisted of 20 albino rats, 12 males and 8 females, from the Wistar strain. All animals were 25 days old and weighed between 29 and $40 \mathrm{~g}$ at the beginning of the experiment.

\section{APPARATUS AND PROCEDURE}

At the time of weaning $(24$ days $)$, all Ss were individually housed in suspended wire cages measuring $10 \times 6 \times 8$ in. Ss were then assigned randomly to one of three experimental groups or a control group, five Ss per group, with the restriction that each group had three males and two females. Beginning 1 day after weaning and continuing for a period of 35 consecutive days, the three experimental groups received 7,14 , or $28 \mathrm{mg} / \mathrm{kg}$ of TRIAP suspended in a $3 \%$ tragacanth solution. The fourth group received a control injection of $3 \%$ tragacanth. During the entire period, food and water were available ad lib. One-half hour following the 32nd drug injection, each animal and its corresponding water bottle were weighed. The procedure was repeated following the 35 th injection. The mean weight per animal and the amount of water consumed over this 3-day period were recorded.

RESULTS AND DISCUSSION

An analysis of variance on the data indicated no significant differences in mean water consumption for the four groups $(\mathrm{F}<1 ; \mathrm{df}=3,16 ; \mathrm{p}>.05)$. Because it is possible that the weight of the animal could affect water consumption, an analysis of variance was performed on the weight of the animals in the four groups, and no significant differences were found $(\mathrm{F}<1 ; \mathrm{df}=3,16 ; \mathrm{p}>.05)$. Table 1 shows the mean body weight and water consumption for each of the experimental conditions.

The results of this study indicate that chronic injections of TRIAP cause no significant change in water consumption. Since an earlier study (Gurowitz, 1969) demonstrated an increase in water intake with acute administrations, it is possible that some type of tolerance to the drug may have developed and, therefore, masked drug-related changes in water consumption.

It is doubtful that differences in weight selectively affected water consumption, since weight differences between the groups did not differ significantly. This lack of weight loss among the TRIAP groups is in contrast to data reported by Schmidt \& Davenport (1967). This contradiction may be explained on the basis of procedural differences. Specifically, Schmidt and Davenport found the greatest weight decrements when drug administration began at conception or at birth. The present study began administration at weaning.

Because the motivational properties of TRIAP should be considered when assessing its effects in a water-reinforced task, it becomes important to determine how long the tolerance period is and if it varies as a function of the drug dosage. Since the present study measured water consumption only once and at this time no systematic effects were found as a function of drug dose, these questions cannot presently be answered. Had water consumption been measured earlier at several points, the effects of the treatments might have appeared. It is suggested that future studies should begin to measure water intake at an earlier time.

While it appears that a tolerance mechanism is operating, it is possible that the onset of tolerance is dose related. Due to this, Es using shorter periods of administration or higher drug doses than used in this study should exercise caution when employing a water-motivated task. Further caution should be exercised when injections are begun prior to weaning, since weight differences between groups may tend to influence water consumption.

Table 1

Mean Body Weight and Water Consumption for the Last 3 Days of Treatment Administration

\begin{tabular}{lcrrr} 
& \multicolumn{4}{c}{ Drug Level } \\
\cline { 2 - 5 } & $\begin{array}{c}3 \% \text { Tra- } \\
\text { gacanth }\end{array}$ & $\begin{array}{c}7 \mathrm{mg} / \mathrm{kg} \\
\text { TRIAP }\end{array}$ & $\begin{array}{c}14 \mathrm{mg} / \mathrm{kg} \\
\text { TRIAP }\end{array}$ & $\begin{array}{r}28 \mathrm{mg} / \mathrm{kg} \\
\text { TRIAP }\end{array}$ \\
\cline { 3 - 5 } & & 79.5 & 62.0 & $\mathbf{7 5 . 2}$ \\
Mean water consumption in grams & 72 & 149.0 & 137.2 & 156.4 \\
\hline
\end{tabular}


EG I H A Z REFERENCES

E.. \& HY DEN, $H$. induced changes in the base composition of ribonucleic acids of isolated nerve cells and their oligdendroglial cells. Joumal of Biophysiology \& Biochemical Cytology $1961,10,403-410$.
GLROWITZ, E. M. Effects of TCAP on water intake in the ral. Psychonomic Science. 1969, 17, 287

GUROWITZ, E. M.. GROSS, D. A.. \& GEORGE. R. Effects of TCAP on passive avoidance learning in the rat. Psychonomic Science. 1968, 12, 293-294. IIORSE. D. L.. \& SOLOMON. P. R. The effects of tricyanoaminopropene on learning in a differential reinforcement of low rates situation. Psychonomic Science. $1970,20,3-4$.

SCHYIDT, II. J.. \& DAVENPORT, J. W TCAP: Facilitation of learning in hyperthyroid rats. Psychonomic Science, $1967,7,185-186$

\section{NOTES \& NEWS}

Here we go again with another try at Notes \& News. There will probably be more this month than at any other time, but we would like to have this a lively column and would appreciate your contributions to it.

Several people are on sabbatical or on leaves of absence this year. M. E. Bitterman is at the University of Hawaii, and William A. Calhoun is a NSF Science Faculty Fellow at Indiana University. Irving Biederman is at Stanford University and Gardner Lindzey, John C. Loehlin, and Frederick C. Newman are "thinking" at the Center for Advanced Studies.

Harold Babb has moved from the University of Montana to become Professor and Chairman of the Department of Psychology at the State University of New York at Binghamton.

Robert A. Baron and Dale W. Leonard are now at Purdue University, Baron moving from the University of South Carolina and Leonard from the University of Rochester.

Richard S. Bogartz has recently moved from the University of Illinois Urbana-Champaign campus to the University of Massachusetts where he is Professor of Psychology and Area Head of the Child Psychology Program.

Robert M. Boynton former Director, Center for Visual Studies at the University of Rochester has become Chairman of its Psychology Department.

Thomas S. Brown has moved from Michael Reese Hospital to DePaul University.

George C. Crampton is Professor in the Department of Psychology at Wright State University, moving from his position as Chief, Psychology Branch, Medical Research Laboratory, Edgewood Arsenal.

Also at Wright State University is A. C. McKinney, where he is Dean of Graduate Studies.

John S. Fletcher, after 20 years in the Army, is now holding a joint appointment in psychology and speech at Memphis State University.

Laird W. Heal has accepted the position of director for a project to evaluate the effectiveness of integrated management procedures for the treatment of cerebral palsied at Northern Wisconsin Colony and The University of Wisconsin at Eau Claire. $\mathrm{He}$ also holds the rank of associate professor in the Psychology Department.

Ronald R. Hutchinson is Director of Research at Fort Custer State Home but has kept his affiliation with Western Michigan UNiversity.

Arnold Hyman has recently become Assistant Professor at Yale University.

Harry Kaufman is Professor of Psychology at Hunter College of the City University of New York.

J. D. Keehn, for some years associated with the Addiction Research Foundation part time, has moved over to York University's Atkinson College full time.

Roy Lachman and Janet Mistler-Lachman were appointed Professor and Assistant Professor, respectively, at the University of Kansas. Roy formerly was Professor of Psychology at SUNY, Buffalo, where Janet Mistler received her PhD in 1971.

Joe Lewis has been appointed Assistant Professor at the University of Texas in Arlington replacing Frank Cheavens who has become Professor Emeritus.

Jared Jay Look has become Assistant Professor of Psychology at the University of Connecticut in Waterbury.

William A. Mason has moved from the Delta Regional Primate Laboratory to the Psychology Department and the National Center for Primate Biology at the University of California, Davis.

Michael M. Patterson has accepted the position of Assistant Professor of Physiology at the Kirksville College of Osteopathic Medicine in Missouri.

John R. Platt has moved from the University of Iowa to McMaster University, where he is Associate Professor of Psychology.

Oakley S. Ray has moved from Pittsburgh, Pennsylvania, to Nashville, Tennessee, where he is now Professor,
Department of Psychology, Associate Professor, Department of Pharmacology, George Peabody College, and Chief, Psychology Service, Veterans Administration Hospital. $\mathrm{He}$ is training director of an interdepartmental graduate training program in neurobiology which emphasizes the field of psychopharmacology and animal developmental psychology.

Charles E. Rice has moved from the Stanford Research Institute to Kenyon College in Gambier, Ohio, where he is Chairman and Professor in the Department of Psychology.

T. T. Sandel is Chairman, Department of Psychology, Washington University.

Robert W. Schaeffer has gone from Florida State University to Auburn University, where he is Professor and Head of the Psychology Department.

Richard A. Schmidt Managing Editor of the Journal of Motor Behavior, has moved the editorial office to the Department of Physical Education, University of Michigan, where he is Associate Professor and Director of the new Motor Behavior Laboratory.

Kirk H. Smith has left Bell Laboratories in Murray Hill to become Associate Professor of Psychology at Bowling Green State University.

Ronald S. Tikofsky has moved from the University of Michigan to Florida International University where he will be Chairman of the Devartment of Psychology and Director of the Division of Social Sciences when that institution opens its doors in the fall of 1972 . He is currently building a Psychology Department there.

Viejo Virsu, after several years in the United States and a year in England, is now back at the Psychological Laboratories at the University of Helsinki.

Morton M. Weir became Vice Chancellor for Academic Affairs at the Urbana-Champaign campus of the University of Illinois on November 1. 